\title{
NOTE
}

\section{Effects of giant protozoans (class: Xenophyophorea) on deep-seamount benthos}

\author{
Lisa A. Levin, David J. DeMaster, Linda D. McCann \& Cynthia L. Thomas \\ Department of Marine, Earth, and Atmospheric Sciences, North Carolina State University, Raleigh, North Carolina 27695-8208, USA
}

\begin{abstract}
Biogenic sediment structures have been proposed to enhance diversity in deep-sea sediments. To evaluate this hypothesis we examined the influence of xenophyophores, giant sediment-agglutinating protozoans, on the structure of metazoan communities inhabiting sediments of deep (1000 to $3300 \mathrm{~m})$ seamounts in the eastern Pacific Ocean. Xenophyophores provided habitat for 16 major metazoan taxa. Sediments immediately surrounding xenophyophores exhibited elevated faunal densities and species richness relative to control sediments collected $1 \mathrm{~m}$ from the tests. Amphipods were exclusively associated with the protozoan tests or sediments beneath them. Crustaceans, molluscs, and echinoderms exhibited enhanced infaunal densities in the presence of xenophyophores but polychaetes did not. Both horizontal and vertical distributions of infauna appear to be influenced by these protozoans. ${ }^{234} \mathrm{Th}$ measurements suggest that xenophyophores and their associated fauna increase the particle flux of fine-grained material to the seabed and enhance subsurface mixing on a $100 \mathrm{~d}$ time scale. We propose that xenophyophores alter hydrodynamic conditions and provide deep-sea metazoans with substrate, food, and refuge. The resulting habitat heterogeneity may contribute to maintenance of high benthic diversity.
\end{abstract}

The benthic fauna of the deep sea is noted for unusually high diversity relative to shallow-water fauna (Hessler \& Sanders 1967, Sanders 1968). Among the many explanations offered for elevated deep-sea diversity (reviewed in Rex 1983), the habitat heterogeneity hypothesis (Jumars 1975, 1976) has received much recent attention (Thistle 1979, 1983, Jumars \& Eckman 1983, Gooday 1984). Biologically produced sediment structures, such as mounds, tubes, tests, fecal casts, burrows, and tracks, may enhance diversity in one of 2 ways. Biogenic structures may persist for long periods under highly stable conditions in the deep sea and provide microhabitats within which species can specialize on different resources (Jumars 1975, Thistle 1979, Gooday 1984). In shallow environments, where the frequency of disturbance is orders of magnitude higher (Thistle 1981), such structures are likely to be obliterated rather quickly. Alter- natively, local disturbances in the deep sea may allow species with similar resource requirements to coexist below carrying capacity (Grassle \& Sanders 1973, Jumars \& Eckman 1983)

One important group of biogenic structures in the deep sea is comprised of the tests produced by giant. sarcodine protozoans of the class Xenophyophorea (Tendal 1972). Xenophyophores are common epifauna at depths greater than $500 \mathrm{~m}$ in regions of the Atlantic, Indian, and Pacific oceans exhibiting high surface productivity or topographic relief (Tendal 1972, Levin unpubl.). Xenophyophores agglutinate sediments to form large tests ( 0.5 to $25 \mathrm{~cm}$ diameter) which protrude above the seabed (Tendal 1972). In this paper we examine the influence of xenophyophores on the composition, diversity, and spatial distribution of sediment-dwelling assemblages on deep (1000 to $3300 \mathrm{~m})$ seamounts in the eastern Pacific Ocean. We evaluate whether xenophyophores, which are abundant on seamounts (Levin 1984), provide the sort of habitat heterogeneity which could contribute to maintenance of high faunal diversity.

Most of our knowledge of xenophyophores has been derived from analyses of bottom photographs (Lemche et al. 1976, Tendal \& Lewis 1978, Tendal \& Gooday 1981), or from haphazard collection of specimens (often damaged) in benthic sled hauls (Tendal 1972, Gooday 1983, 1984) or box cores (Tendal et al. 1982). Use of the submarine ALVIN has allowed observation and collection of intact xenophyophores.

Materials and methods. Box cores, each containing 4 square subcores $(7 \times 7 \times 15 \mathrm{~cm})$, were collected from 7 sites on 4 seamounts in the eastern Pacific Ocean off Mexico (Table 1). One pair of cores was taken at each site. One core in each pair sampled a xenophyophore and underlying sediment, the other was taken less than $1 \mathrm{~m}$ away over sediment with no visible biogenic structures. Six xenophyophore tests were recovered 
Table 1. Dive sites and faunal abundances for a study of xenophyophore effects on infauna. Paired box cores $\left(196 \mathrm{~cm}^{2}\right)$ were taken at each site, 1 over a xenophyophore and 1 as a control

\begin{tabular}{|c|c|c|c|c|c|c|c|c|c|c|c|c|}
\hline \multirow[b]{2}{*}{$\begin{array}{l}\text { Alvin } \\
\text { Dive }\end{array}$} & \multirow[b]{2}{*}{$\begin{array}{l}\text { Sea- } \\
\text { mount }\end{array}$} & \multirow[b]{2}{*}{ Lat. } & \multirow[b]{2}{*}{ Long } & \multirow[b]{2}{*}{$\begin{array}{l}\text { Sample } \\
\text { depth } \\
\text { (m) }\end{array}$} & \multirow[b]{2}{*}{$\begin{array}{l}\% \\
\text { Silt- } \\
\text { clay }\end{array}$} & \multirow[b]{2}{*}{ Substrate } & \multicolumn{6}{|c|}{ Number of individuals per core } \\
\hline & & & & & & & $\begin{array}{c}\text { Ma- } \\
\text { crofauna } \\
\text { xcicc }\end{array}$ & $\begin{array}{l}\text { Poly- } \\
\text { chaetes } \\
\mathrm{xc} / \mathrm{cc}\end{array}$ & $x c / c c$ & $\begin{array}{l}\text { Pera- } \\
\text { carid } \\
\text { crusta- } \\
\text { ceans } \\
\text { xcicc }\end{array}$ & $\begin{array}{l}\text { Echino- } \\
\text { derms }\end{array}$ & $\begin{array}{l}\text { Meio- } \\
\text { fauna } \\
\mathrm{xc} / \mathrm{cc}\end{array}$ \\
\hline 1389 & 6 & $12^{\circ} 45^{\prime} \mathrm{N}$ & $102^{\circ} 35^{\prime} \mathrm{W}$ & 1775 & 12.2 & Foram sand & $28 / 22$ & $11 / 18$ & $1 / 0$ & $8 / 2$ & $4 / 0$ & $53 / 46$ \\
\hline $1390^{\circ}$ & 6 & $12^{\circ} 40^{\prime} \mathrm{N}$ & $102^{\circ} 35^{\prime} \mathrm{W}$ & 3009 & 83.2 & Metalliferous mud & $43 / 32$ & $19 / 19$ & $4 / 1$ & $8 / 5$ & $1 / 3$ & $274 / 243$ \\
\hline 1393 & 7 & $13^{\circ} 20^{\prime} \mathrm{N}$ & $102^{\circ} 30^{\prime} \mathrm{W}$ & 1790 & 24.7 & Foram sand & $35 / 20$ & $13 / 17$ & $4 / 1$ & $8 / 0$ & $7 / 0$ & $22 / 24$ \\
\hline 1394 & 7 & $13^{\circ} 15^{\prime} \mathrm{N}$ & $102^{\circ} 31^{\prime} \mathrm{W}$ & 2850 & 75.2 & Metalliferous mud & $35 / 20$ & $13 / 13$ & $3 / 1$ & $11 / 2$ & $3 / 0$ & $234 / 75$ \\
\hline $1395^{\circ}$ & 7 & $13^{\circ} 27^{\prime} \mathrm{N}$ & $102^{\circ} 37^{\prime} \mathrm{W}$ & 3353 & - & Metalliferous mud & $15 / 22$ & $5 / 13$ & $0 / 1$ & $6 / 1$ & $0 / 0$ & $85 / 70$ \\
\hline 1397 & 5 & $12^{\circ} 56^{\prime} \mathrm{N}$ & $103^{\circ} 29^{\prime} \mathrm{W}$ & 1247 & 30.1 & Mn, Fe oxides & $35 / 27$ & $14 / 17$ & $5 / 1$ & $2 / 0$ & $4 / 2$ & $19 / 20$ \\
\hline \multirow[t]{5}{*}{1469} & $\begin{array}{c}\text { NW } \\
\text { Bonanza }\end{array}$ & $31^{\circ} 11^{\prime} \mathrm{N}$ & $122^{\circ} 15^{\prime} \mathrm{W}$ & 2776 & 67.4 & Calcareous ooze & $21 / 13$ & $18 / 6$ & $0 / 0$ & $2 / 1$ & $0 / 0$ & $118 / 37$ \\
\hline & & & & & & Total & $212 / 156$ & $93 / 103$ & $17 / 5$ & $45 / 11$ & $19 / 5$ & $805 / 515$ \\
\hline & & & & & & $\bar{x} \pm 1 \mathrm{SD}$, Xeno core & $\begin{array}{r}29.5 \\
\pm 9.4 i\end{array}$ & $\begin{array}{r}13.3 \\
\pm 4.3 /\end{array}$ & $\begin{aligned} & 2.3 \\
\pm & 2.11\end{aligned}$ & $\begin{array}{c}6.4 \\
\pm 3.1 /\end{array}$ & $\begin{array}{c}2.7 \\
\pm 2.4 /\end{array}$ & $\begin{array}{r}115.0 \\
\pm 94.2\end{array}$ \\
\hline & & & & & & Control core & $\begin{array}{l}22.3 \\
\pm 5.5\end{array}$ & $\begin{array}{l}14.7 \\
\pm 4.2\end{array}$ & $\begin{array}{c}0.9 \\
\pm 0.4\end{array}$ & $\begin{array}{c}1.6 \\
\pm 1.6\end{array}$ & $\begin{array}{l}0.7 \\
\pm 1.16\end{array}$ & $\begin{array}{c}73.6 \\
\pm 71.6\end{array}$ \\
\hline & & & & & & Paired t test: $\begin{aligned} t_{6} & = \\
P & =\end{aligned}$ & $\begin{array}{l}2.83 \\
<.05\end{array}$ & $\begin{array}{l}0.57 \\
\text { NS }\end{array}$ & $\begin{array}{l}2.52 \\
<.05\end{array}$ & $\begin{array}{l}4.86 \\
<.01\end{array}$ & $\begin{array}{l}1.76 \\
\text { NS }\end{array}$ & $\begin{array}{l}1.85 \\
\text { NS }\end{array}$ \\
\hline $\begin{aligned} & x c=x \\
& c c=c c \\
& \cdot \text { The } \\
& \cdots \text { Som }\end{aligned}$ & $\begin{array}{l}\text { no core } \\
\text { ntrol core } \\
\text { xeno core } \\
\text { e organisn }\end{array}$ & $\begin{array}{l}\text { may contal } \\
\text { ns were los }\end{array}$ & $\begin{array}{l}\text { in some te } \\
\text { st from the }\end{array}$ & habit & ta: & Dlete closure & & & & & & \\
\hline
\end{tabular}

intact. Sediments were sectioned at 0 to 2 and 2 to $10 \mathrm{~cm}$ intervals prior to sieving. All material was preserved in $10 \%$ buffered formalin. Infaunal data reported are for macro- and meiofaunal taxa retained on a $297 \mu \mathrm{m}$ screen. Within-core distributions of infauna were examined for 2 box cores in which a xenophyophore was collected within a single subcore. Six additional xenophyophores were recovered in cylindrical pushcores $(7 \mathrm{~cm}$ diam $\times 15 \mathrm{~cm}$ ). AII material from the xenophyophore tests was sieved through a $63 \mu \mathrm{m}$ screen in the laboratory.

Two cylindrical cores $(7 \mathrm{~cm}$ diam $\times 15 \mathrm{~cm})$, collected on Dive 1469, were sectioned at $1 \mathrm{~cm}$ intervals to a depth of $5 \mathrm{~cm}$ for analysis of ${ }^{234} \mathrm{Th} .{ }^{234} \mathrm{Th}$ is a naturally occurring radioisotope with a half life of $24 \mathrm{~d}$ which can be used to establish rates of sedimentary processes on a $100 \mathrm{~d}$ time scale (Aller \& DeMaster 1984). After adding a ${ }^{228} \mathrm{Th} /{ }^{232} \mathrm{U}$ spike to monitor chemical yield, ${ }^{234} \mathrm{Th}$ was extracted from 5 to $10 \mathrm{~g}$ of dried sediment over a period of $5 \mathrm{~h}$ using a near-boiling $6 \mathrm{~N} \mathrm{HCl}$ solution. Thorium was isolated using ion exchange and TTA extraction techniques. The activity of ${ }^{234}$ Th was measured by detecting the beta decay of ${ }^{234} \mathrm{Th}$ and its short-lived daughter, ${ }^{234} \mathrm{~Pa}$, on a low-level beta counting system.

Results and discussion. Five types (genera?) of xenophyophore tests were collected on the seamounts including 2 reticulate forms from foram sands (Fig. $1 \mathrm{~A}$, $B, C)$ and 3 platy xenophyophores from metalliferous muds (Fig. 1 D, E) and calcareous ooze (Fig. 1F). A semifossilized hexactinellid skeleton was sampled from hydrothermal deposits (Dive 1397) and has been included in this discussion because of the similarity in functional effects.

We found 109 macrofaunal individuals and 79 meiofaunal individuals inhabiting the 12 xenophyophore tests. Polychaetes and ophiuroids each comprised $31 \%$ of the macrofauna, followed in abundance by isopods $(15 \%)$, amphipods (4\%), and sipunculans, tanaids and sponges (each $3 \%$ ). Gastropods, bivalves, echinoids, tardigrades, and ascidians were each represented by 1 or 2 individuals. Meiofaunal taxa included nematodes $(57 \%)$, harpacticoid copepods $(39 \%)$ and ostracods (4\%). Thirty-three $\%$ of all the macrofauna and $39 \%$ of all the meiofauna reported were found in the largest test examined (Fig. 1 B). A previous report of metazoans inhabiting rhizopod tests (Gooday 1984) documents many of the same taxa but cites dominance by sipunculans, which were preferentially associated with a particular foraminiferan. We observed a family grouping of 10 nannoniscid isopods (Hebefustis sp.) within the largest test, suggesting that the tests provide a semipermanent residence. However, some specimens recovered from the tests, such as pardaliscid 

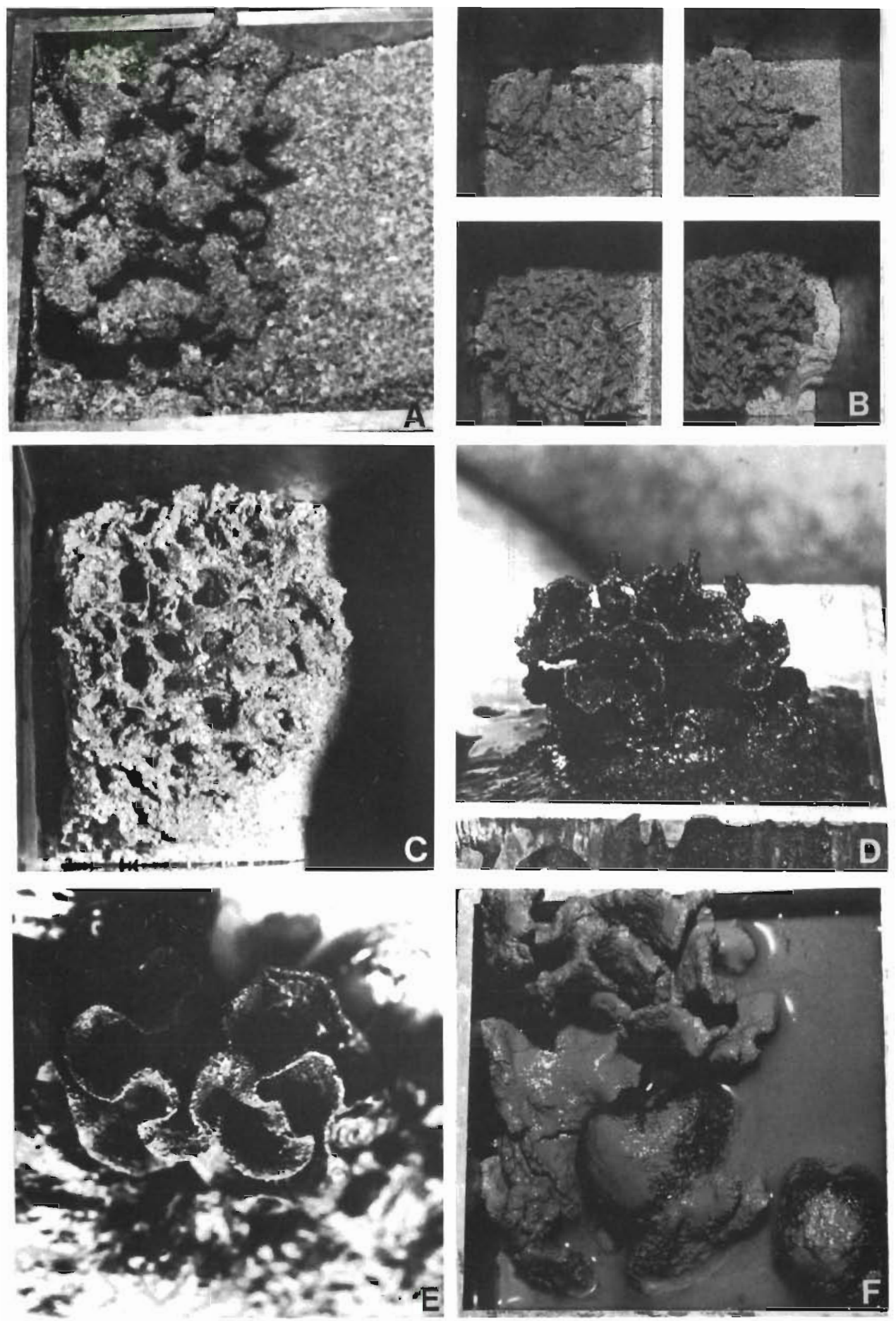

Fig. 1. Xenophyophore tests collected in box cores. (A) Dive 1389, Galatheammina sp., $6 \mathrm{~cm}$ longest dimension, $1775 \mathrm{~m}$. (B) Dive 1393. Reticulammina sp., $13 \mathrm{~cm}$ diameter, $1790 \mathrm{~m}$. (C) Closeup of lower right replicate shown in (B). (D) Dive 1394, Psammina sp.A., $4 \mathrm{~cm}$ diameter, $2850 \mathrm{~m}$. (E) Dive 1395, Psammina sp.B., $4 \mathrm{~cm}$ diameter, $3353 \mathrm{~m}$. (F) Dive 1469 , unidentified, $5 \mathrm{~cm}$ longest dimension, $2776 \mathrm{~m}$. Identifications by $\mathrm{O}$. Tendal 
amphipods and polynoid polychaetes, are highly mobile forms.

Sediments beneath and near xenophyophore tests contained more macrofauna $(\bar{x}=29.5$ individuals core $\left.^{-1}\right)$ than control sediments $(\overline{\mathrm{x}}=22.3$ individuals core $\left.^{-1}\right)\left(t_{6}=2.83, p<0.05\right)$. The total abundance of polychaetes was unaffected by the presence of xenophyophores, but molluscs (bivalves, gastropods, aplacophorans and polyplacophorans), peracarid crustaceans (amphipods, isopods, and tanaids), and echinoderms (ophiuroids, echinoids, and holothuroids) were each 3 to 4 times more abundant in sediments beneath xenophyophores than in control cores (Table 1). Amphipods (10 individuals), collected at 5 sites, were found exclusively associated with xenophyophores. Amphipods may have been more likely to escape from control sediments during sampling due to the absence of a refuge. Macrofaunal species richness was higher in cores with xenophyophores (126 infaunal species) than in control cores (91 infaunal species). Rarefaction analysis (Smith \& Grassle 1977) indicates increased macrofaunal diversity beneath xenophyophores at 3 sites and no difference from controls at 4 sites. Differences in species composition which are observed between xenophyophore and control assemblages (there being only $25 \%$ species overlap) collectively enhance the overall diversity of seamount sediments.

Small-scale $(<15 \mathrm{~cm})$ horizontal distributions of infauna were examined for 2 box cores (Dives 1389 and 1394) in which the xenophyophore tests were re- covered cleanly within 1 of 4 subcores (Fig. 2). In both cores total faunal density and species richness were enhanced in the xenophyophore-bearing subcore (Fig. 2). It should be noted that elevated species richness in the xenophyophore-bearing subcores was simply a result of higher faunal abundances. No diversity differences (based on rarefaction analysis) were detected among subcores within each of the 2 boxcores. Preferential association with the xenophyophore (within a box core) was observed for peracarid crustaceans in coarse- $\left(\chi_{1}^{2}=16.7, p<0.005\right)$ and finegrained $\left(\chi_{1}^{2}=5.12, p<0.025\right)$ sediments and for harpacticoid copepods $\left(\chi_{1}^{2}=87.2, p<0.005\right)$ and nematodes $\left(\chi_{1}^{2}=23.7, \mathrm{p}<0.005\right)$ in fine-grained sediments (Fig. 2). For these taxa the xenophyophore influence probably occurs within a few centimeters of the test.

The presence of xenophyophores in cores correlates with an upward shift in the vertical distributions of infauna. In foram sands the top $2 \mathrm{~cm}$ of the control box cores contained only $42 \%$ of the total macrofauna and $46 \%$ of the total meiofauna. Near-surface sediments beneath xenophyophores $(0$ to $2 \mathrm{~cm}$ ) contained a significantly greater proportion of the macrofauna (75\%) and meiofauna $(76 \%$ ) (arcsin transformation, $\mathrm{p}=$ 0.0002 ). Macrofaunal and meiofaunal densities in the 2 to $10 \mathrm{~cm}$ fraction of xenophyophore-bearing cores were half those in control cores despite higher overall $(0$ to $10 \mathrm{~cm}$ ) infaunal abundance in the former group. In metalliferous muds the vertical distribution of macrofauna was unaffected by the presence of xenophyophores. However, a greater proportion of meiofauna
MACROFAUNAL TAXA

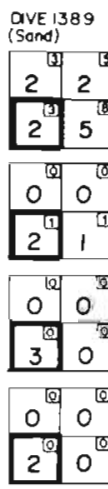

NONE

\begin{tabular}{|c|c|}
\hline 1 & 0 \\
\hline 0 & 0 \\
\hline
\end{tabular}

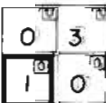

AVE 1394 QVEv 1394

POLYCHAETA $44^{4} 0^{2}$



\begin{tabular}{lll}
$5^{\circ}$ & $0^{\circ}$ \\
\hline
\end{tabular}

ISOPODA

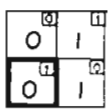

AMPHIPODA

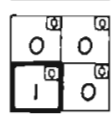

BIVALVA

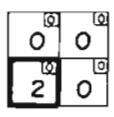

APLACOAHORA

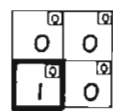

OPHIUROIOEA

NONE
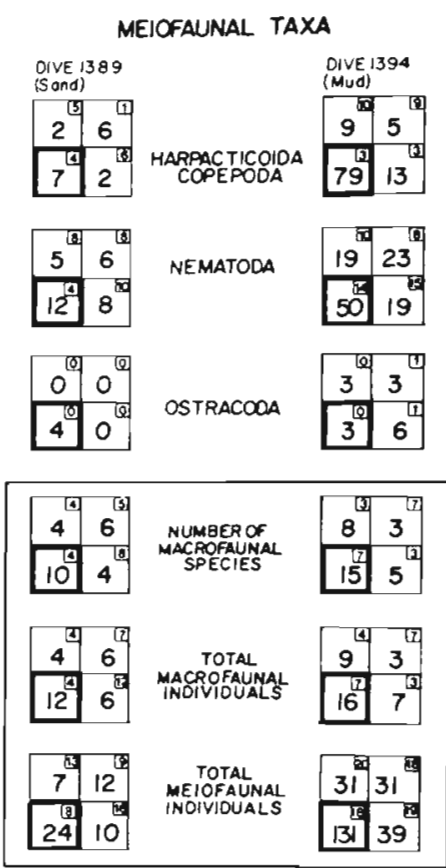

Fig. 2. Distribution of infauna among subcores $(7 \times 7 \times 10 \mathrm{~cm})$ within 2 ALVIN box cores. In each of the 2 cores the xenophyophore was located within a single subcore (bold lines). Numbers given are the infauna retained on a $297 \mu \mathrm{m}$ screen. Numbers in the upper right of each subcore are values for control cores taken approximately $1 \mathrm{~m}$ away. Chi square analyses of numbers of individuals and numbers of species within versus outside the xenophyophore-bearing subcore are as follows. Total number of macrofaunal species: Dive 1389, $\chi_{1}^{2}=3.55,0.1<p<0.5 ;$ Dive 1394, $\chi_{1}^{2}=9.04$ $\mathrm{p}<0.005$. Total number of macrofaunal individuals: Dive 1389, $\chi_{1}^{2}=4.76, p<.05$; Dive 1394, $\chi_{1}^{2}=8.01, p<0.005$. Total number of meiofaunal individuals: Dive 1389, $\chi_{1}^{2}=11.63$. $p<0.005 ;$ Dive 1394, $\chi_{1}^{2}=122.50, p<0.005$ Although macrofaunal species richness was elevated in the xenophyophore-bearing subcores, rarefaction analyses indicate no diversity enhancement in those subcores 
occurred in the top subsample from the mud cores containing xenophyophores $(84 \%)$ than in control cores $(78 \%)(p=0.0240)$.

Several hypotheses can be advanced to explain xenophyophore influences on metazoan composition, abundance, and distribution. The xenophyophore tests provide additional living space, above and possibly below the sediment-water interface, by increasing the amount of surface area available. One common test inhabitant, a flabelligerid polychaete, has been found in a sheath constructed of xenophyophore fecal material (stercomata). The tests may function as a structural refuge from large epifaunal predators and grazers, as was proposed by Gooday (1984). Small ophiuroids were extremely abundant (25 individuals) in the reticulate test shown in Fig. 1B. Camera sled photographs showed large (5 to $10 \mathrm{~cm}$ ) ophiuroids frequently residing beneath xenophyophore tests and urchin traces which markedly detour towards and circle xenophyophore tests (Levin unpubl.). Juveniles and small individuals in the deep sea may gain protection from their association with xenophyophore tests in the same manner that juvenile urchins and abalone gain refuge from predators under urchin spine canopies in California kelp forests (Tegner \& Dayton 1977). Portions of the rhizopod tests anchored beneath the sediment surface may also inhibit predation on infauna by epifauna and stabilize sediments as seagrass roots do in shallow water (Orth 1977, Peterson 1982).

Xenophyophore protoplasm (Tendal 1985) and stercomata (Tendal 1979), other test inhabitants, and trapped organic particulates, may serve as additional food sources in an environment where food is generally believed to be a limiting resource (Rowe 1983). Stercomata are accessible to metazoan test inhabitants which burrow into test surfaces (e.g. nematodes) and may become exposed when portions of a test break. Stercomata are thought to have elevated bacterial growth rates (Tendal 1979), of great potential value to sediment-ingesting species. Feeding on xenophyophores has been reported for monoplacophorans (Tendal 1985) and may extend to many other taxa. In addition, the test structures themselves are likely to alter the hydrodynamic and sedimentary regimes in their immediate vicinity, much as do tubes or other biogenic structures (Nowell \& Jumars 1984). Resulting microhabitat differences could alter patterns of microbial growth, faunal recruitment, and feeding (Jumars \& Nowell 1984), and thereby select for differing lifestyles.

Passive modification of near-bottom flow and active behavior of xenophyophores and their associated fauna may modify particle flux from the water column and the distribution of particles within the seabed. ${ }^{234} \mathrm{Th}$ (a naturally occurring tracer of water-column particulate material deposited during the past $100 \mathrm{~d}$ ) was measured in 2 cores collected from the caldera floor of NW Bonanza seamount $(2776 \mathrm{~m})$. One core was collected over a xenophyophore, whereas the other was a control core collected $1 \mathrm{~m}$ away. Sediments within and beneath the xenophyophore test contained 3 times the ${ }^{234} \mathrm{Th}$ activity of control sediments $(4.4 \mathrm{dpm}$ $\mathrm{cm}^{-2}$ versus $1.3 \mathrm{dpm} \mathrm{cm} \mathrm{cm}^{-2}$ ) (Fig. 3), suggesting enhanced deposition of fine-grain particles in the vicinity
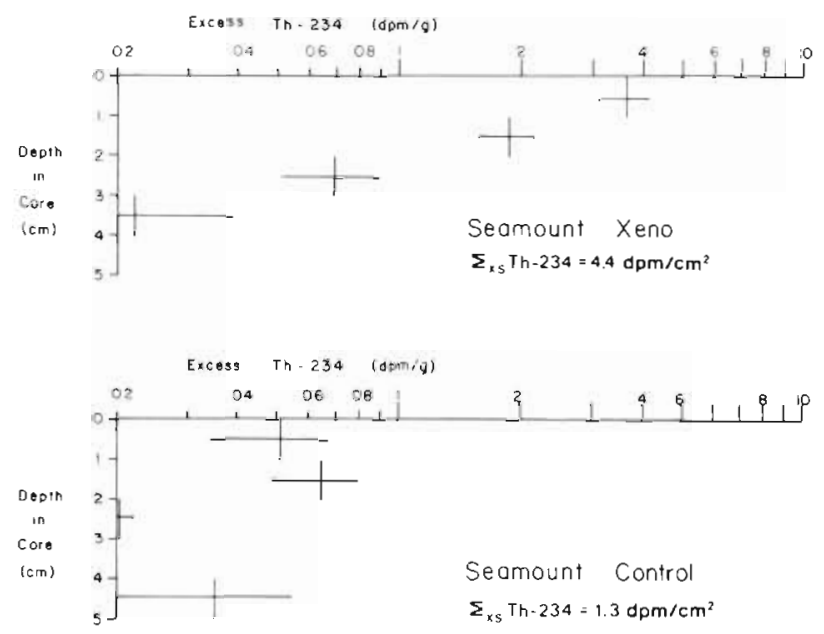

Fig. $3 .{ }^{234}$ Th profiles for 2 sediment cores $(7 \mathrm{~cm}$ diam $\times 15 \mathrm{~cm}$ deep) collected on the $\mathrm{Mn}$ nodule covered floor of $\mathrm{NW}$ Bonanza Seamount $\left(31^{\circ} \mathrm{N} 122^{\circ} \mathrm{W}\right), 2776 \mathrm{~m}$. The upper profile is from a core collected over a xenophyophore similar to that in Fig. $1 \mathrm{~F}$. The xenophyophore occupies the top $1 \mathrm{~cm}$. The lower profile was collected from control sediments $1 \mathrm{~m}$ away

of the xenophyophore during the $100 \mathrm{~d}$ prior to collection. Excess ${ }^{234}$ Th activity was observed to a depth of $3 \mathrm{~cm}$ in the core containing the xenophyophore, indicating that particles from the sediment-water interface have been transported to this depth on a $100 \mathrm{~d}$ time scale. Assuming that ${ }^{234} \mathrm{Th}$ penetration into the seabed is a result of biological mixing, the mixing intensity can be characterized by modeling the slope of the ${ }^{234} \mathrm{Th}$ profile. The ${ }^{234} \mathrm{Th}$ data from the xenophyophore core yield a mixing coefficient $\left(\mathrm{D}_{\mathrm{b}}\right)$ of $17 \mathrm{~cm}^{2} \mathrm{yr}^{-1}$, which is an order of magnitude greater than typical open-ocean mixing coefficients (DeMaster \& Cochran 1982), but comparable to values from Panama Basin (Aller \& DeMaster 1984). Enhanced abundances of infauna associated with the xenophyophore at that site (see Table 1, Dive 1469) are probably responsible for the high intensity of mixing.

Further study and experimentation are needed to determine which processes are responsible for the faunal patterns described above. It is likely that other agglutinating protozoans, such as komokiacean foraminifera, exert similar influence on deep-sea communities. From our preliminary findings we conclude 
that xenophyophores, which often attain densities of 1 to 10 ind $\mathrm{m}^{-2}$ (Lemche et al. 1976, Tendal \& Lewis 1978, Levin unpubl. obs.), are an important source of sedimentary and faunal heterogeneity, and as such, may contribute to maintenance of high benthic diversity in the deep sea.

Acknowledgements. We acknowledge support from ONR contract N00014-84-0081 (to L.A.L.) and NSF grant OCE 8308980 (to R. Batiza). Special thanks go to R. Batiza for generously sharing submersible time. We thank the following people for assistance in collection and processing of samples: the captain and crews of the R/V 'Atlantis II' and DSRV 'Alvin', J. Alt, R. Batiza, R. Brett, P. Castillo, K. DePatra, P. Lonsdale, M. McNutt, M. Mottl, T. Simkin, D. Vanko and especially P. Romans and the Alvin pilots. K. Thorbjarnarson assisted with sediment grain-size and radioisotope analyses. The rarefaction program was provided by J.F. Grassle and $M$. Udevitz, W. Cornelius and E. Creed assisted with the analyses. Isopods were identified by G. Wilson. Earlier drafts of this manuscript were critiqued by E. Creed, C. Nittrouer, C. Peterson, C. Smith, O. Tendal and 3 anonymous reviewers.

\section{LITERATURE CITED}

Aller, R. C., DeMaster, D. J. (1984). Estimates of particle flux and reworking at the deep-sea floor using ${ }^{234} \mathrm{Th} /{ }^{238} \mathrm{U}$ disequilibrium. Earth Planet. Sci. Lett. 67: 308-318

DeMaster, D. J., Cochran, J. K. (1982). Particle mixing rates in deep-sea sediments determined from excess ${ }^{210} \mathrm{~Pb}$ and ${ }^{32} \mathrm{Si}$ profiles. Earth Planet. Sci. Lett. 61: 257-271

Gooday, A. (1983). Primitive foraminifera and xenophyophorea in IOS epibenthic sledge samples from the northeast Atlantic. Inst. of Oceanogr Sci., Wormley, Rept. No. 156: $1-33$

Gooday, A. (1984). Records of deep-sea rhizopod tests inhabited by metazoans in the North-east Atlantic. Sarsia 69: 45-53

Grassle, J. F., Sanders, H. L. (1973). Life histories and the role of disturbance. Deep Sea Res. 20: 643-659

Hessler, R. R., Sanders, H. L. (1967). Faunal diversity in the deep sea. Deep Sea Res. 14: 65-78

Jumars, P. A. (1975). Environmental grain and polychaete species diversity in a bathyal benthic community. Mar. Biol. 30: 253-266

Jumars, P. A. (1976). Deep-sea species diversity: Does it have a characteristic scale? J. mar. Res. 34: 217-246

Jumars, P. A., Eckman, J. E. (1983). Spatial structure within deep-sea benthic communities. In: Rowe, G. T. (ed.) Deepsea biology. John Wiley and Sons, New York, p. 399-451

Jumars, P. A., Nowell, A. R. M. (1984). Fluid and sediment dynamic effects on marine benthic community structure. Am. Zool. 24: 45-56

Lemche, H., Hanson, B., Madsen, F. J., Tendal, O. S., Wolff, T.
(1976). Hadal life as analyzed from photographs. Vidensk. Meddr dansk naturh. Foren. 139: 263-336

Levin, L. A. (1984). Xenophyophoria (agglutinating protozoa) structure infauna of deep-sea volcanos. EOS (Trans. Am. geophys. Un.) 45: 918 (Abstract)

Nowell, A. R. M., Jumars, P. A. (1984). Flow environments of aquatic benthos. A. Rev. Ecol. Syst. 15: 303-328

Orth, R. J. (1977). The importance of sediment stability in seagrass communities. In: Coull, B. C. (ed.) Ecology of marine benthos. Univ. South Carolina Press, Columbia, p. $281-300$

Peterson, C. H. (1982). Clam predation by whelks (Busycon spp.): experimental tests of the importance of prey size, prey density and seagrass cover. Mar. Biol. 66: 159-170

Rex, M. A. (1983). Geographic patterns of species diversity. In: Rowe, G. T. (ed.) Deep-sea biology. John Wiley and Sons, New York, p. 453-472

Rowe, G. G. (1983). Biomass and production of the deep-sea macrobenthos. In: Rowe, G. T. (ed.) Deep-sea biology. John Wiley and Sons, New York, p. 97-122

Sanders, H. L. (1968). Marine benthic diversity: A comparative study. Am. Nat. 102: 243-282

Smith, W., Grassle, J. F. (1977). Sampling properties of a family of diversity measures. Biometrics 33: 283-292

Tegner, M. J., Dayton, P. K. (1977). Sea urchin recruitment patterns and implications of commercial fishing. Science 196: 324-326

Tendal, O.S. (1972). A monograph of the Xenophyophoria (Rhizopoda, Protozoa). Galathea Rep. 12: 7-99

Tendal, O. S. (1979). Aspects of the biology of Komokiacea and Xenophyophoria. Sarsia 64: 13-17

Tendal, O.S. (1985). Xenophyophores (Sarcodina, Protozoa) in the diet of Neopilina galatheae (Monoplacophora, Mollusca). Galathea Rep. 16: 95

Tendal, O.S., Gooday, A. (1981). Xenophyophoria (Rhizopoda, Protozoa) in bottom photographs from the bathyal and abyssal NE Atlantic. Oceanologica Acta 4: 415-422

Tendal, O. S., Lewis, K. B. (1978). New Zealand xenophyophores: upper bathyal distribution, photographs of growth position and a new species. N.Z. J. mar. Freshwat. Res. 12: $197-203$

Tendal, O. A., Swinbanks, D. D., Shirayama, Y. (1982). A new infaunal xenophyophore (Xenophyophorea, Protozoa) with notes on its ecology and possible trace fossil analogues. Oceanologica Acta 5: 325-329

Thistle, D. (1979). Harpacticoid copepods and biogenic structures: Implications for deep-sea diversity maintenance. In: Livingston, R. J. (ed.) Ecological processes in coastal and marine systems, Plenum Publ. Corp., New York, p. $217-230$

Thistle, D. (1981). Natural physical disturbances and communities of marine soft bottoms. Mar. Ecol. Prog. Ser, 6 : $223-238$

Thistle, D. (1983). The role of biologically produced habitat heterogeneity in deep-sea diversity maintenance. Deep Sea Res. 30: 1235-1246

Accepted for printing on November 14, 1985 